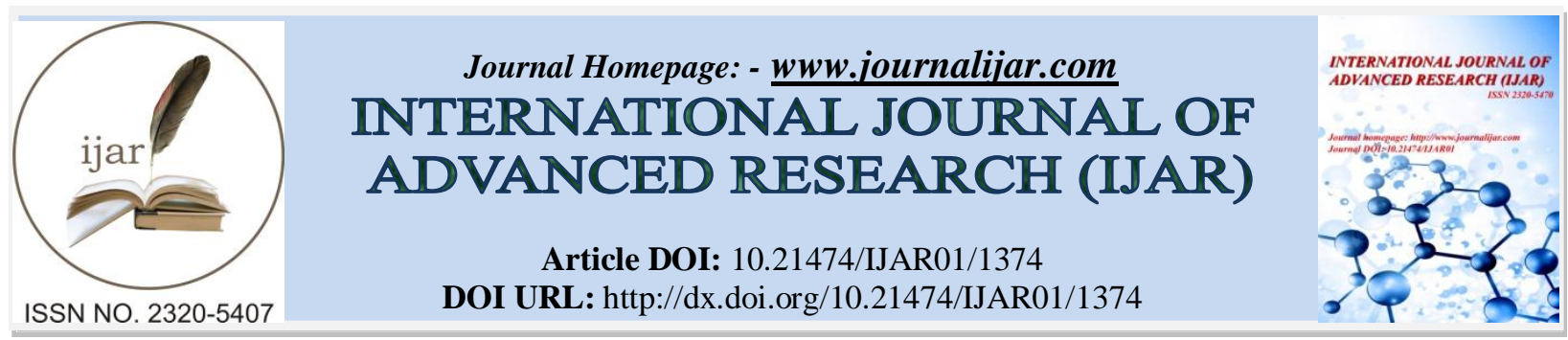

RESEARCH ARTICLE

\title{
ATTITUDE OF STUDENTS/TEACHERS TO THE USE OF INFORMATION COMMUNICATION TECHNOLOGY(ICT) IN THE TEACHING OF ENGLISH LANGUAGE IN SENIOR SECONDARY SCHOOLS IN AWKA, NIGERIA.
}

Obiegbu, Ifeyinwa Rita (Ph.D). Department of English and Literary Studies, University of Nigeria, Nsukka.

\section{Manuscript Info}

\section{Manuscript History}

Received: 12 June 2016

Final Accepted: 19 July 2016

Published: August 2016

Key words:-

Attitude, ICT, e-learning, computer, instruction.

\begin{abstract}
The integration of ICT into education is desirable but it has not been fully exploited in the teaching and learning of English language in many secondary schools in Nigeria. This may not be unconnected with their attitude towards this modem innovation. Against this background, this study is aimed at investigating the attitude of teachers and students to the use of Information and Communication Technology (ICT) in teaching and learning of English at the Senior Secondary School level in Awka. This study adopted a descriptive research design method while simple random sampling technique was used to select 22 out of 74 senior secondary schools in the area. A total of 15 teachers and 296 students were sampled and data were obtained through two distinct instruments designed for the purpose. The reliability co-efficient of the instruments were 75 and 69 respectively. Descriptive statistics of frequency counts and percentages were used to analyze the data. The results revealed that teachers have positive attitude to the use of ICT in teaching while students believed it should be for only those in the sciences. Also, it was revealed that the commonest ICT facilities being used by the respondents were computer and mobile phones while teachers believed that ICT could be used to teach all aspects of English. On the basis of this, it was recommended that the use of ICT should be encouraged in teaching English in schools.
\end{abstract}

\section{Introduction:-}

The integration of Information and Communication Technology (ICT) in education has been a priority in most advanced countries but progress has been uneven especially in the developing countries such as Nigeria. BECTA - British Educational Communication and Technology Agency (2006) reveals that there are considerable differences of e-maturity among various nations. Schools in most countries however are at the early phase of ICT adoption. The Nigerian government realizes the inestimable role of ICT in the National Policy on Education (2004) and states and government shall provide necessary infrastructure and training for 
the integration of ICF in the school system in recognition of the role of ICT in advancing knowledge and skill in the modern world.

Information and Communication Technology (ICT) has been a veritable tool in medicine, commerce, engineering, education etc. As a result of this, we now have e-commerce, e-banking, e-government, e-learning etc. This is to testify to the fact that the educational sector in Nigeria needs to fully integrate ICT into its system in order to benefit from the inexhaustive opportunities that it affords. Kolawole (2006) specifies that language experts and many stakeholders in education have advocated the use of ICT to improve teachers' competence and pedagogical skills as a major way by which the teaching of English Language can be improved. UNESCO (2005) had earlier stated how ICT potentially offers numerous advantages and provides opportunities for facilitating learning for children who have different learning styles and abilities including slow learners, the socially disadvantaged, the mentally and physically handicapped, the talented and those living in remote areas.

Machin (2006) submits that ICT impacts positively on educational performance in secondary schools, especially in English language. He believes that it leads to improvement in the attainment level of students in the subject. This submission was buttressed by Oyinloye (2007) who stresses that ICT facilities are essential to the English teacher and learner, particularly at the senior secondary school level in the following ways:

1. It helps the teacher to arouse the interest of the learners during language lessons.

2. It assists the teacher by throwing more light on the meaning of the utterances made by the teacher,

3. It makes the learners realize the correct articulation of sounds and words,

4. It enables the learners to have the opportunity of listening to native speakers of a particular sound language without necessarily leaving their own country.

All the above put together means that the integration of ICT into teaching and learning of English Language in the senior secondary school will lead to more concentration on the part of the learners towards the subject.

One would expect that the increasing awareness and use of computer-aided instructional packages coupled with the prominence given to English language as a school subject would enhance the performance of candidates in English, particularly in West African Senior School Certificate Examinations. However, this seems not to be the case in Nigeria. The poor performance of candidates in English has been influenced by a number of factors. Some of these factors, according to Renee (1996) are negative attitude towards English, poor instructional strategies, paucity of qualified and dedicated tutors, rote learning resulting from the traditional talk and chalk method of teaching and so on which is an indication that verbal instruction has failed to produce good results in developing countries, Nigeria inclusive. It is believed that if teachers and students want to enhance performance in English, efforts should be made to tap heavily from devices which have direct sensory appeal, hence the need for this paper.

One of the major factors that affect students' performance in English is attitude on the part of both the teachers and the students. Ezeokoli (2000) submits that learning and attitude involve experience and behavior change, making attitude critical in the process of gaining an insight into the solution to problems whether they are social, emotional, educational and language-related problems. A study on attitude is important in discussing issues relating to language acquisition and development, especially as it affects students in a teachinglearning situation. Makinde (2003) reveals that attitude affects what is learned in cognitive, affective and psychomotor domains since it is the attitude of an individual to learning that determines his or her desire to perform, thus making it relatively important to determine the place of attitude to ICT in students' performance in English Language.

This study is hinged on information processing theory propounded by Jerome Brunner in 1964. The theory explains how the brain processes information and stores it in the memory. It posits that information travels upward through different levels of memory but not all information reaching the brain can be retained, as such all information first go to short-term memory (STM) where they stay for a short time and they arc either coded or stored in the long-term memory (LTM) or lost into output.

Owuamanam and Owuamanam (2004) stated that information processing theory views students as being oriented towards learning-seeking, organizing-coding and storing, retrieving and using information throughout life, such that meaningful learning occurs when learners select, organise and build coherent connections of new information with prior knowledge (Mayer, 2001). The teacher, according to the submission of Bradley and Hitch 
(2001), needs to grab the students' attention in order to teach them effectively and to do this, it is imperative to gauge their level of prior information. Besides, multimedia and words cause students to retain more information than word-based lessons alone without multimedia. Therefore, the inclusion of information and communication technology in teaching and learning of English language will reinforce teachers' methodology and learners will be able to make use of their prior knowledge, process information and make use of it in learning situations.

Information and Communication Technology is the scientific method of storing and processing information and correspondingly sharing, exchanging and sending or moving such information from one place to the other (Bamidele, 2001). ICT can be defined to mean computers, ancillary equipment, software, hardware, services and resources interconnected to form network that is used in automatic acquisition, storage, manipulation, management, movement, control, display, switching, interchange etc. of data or information.

Information and Communication Technologies are instructional resources through which information is passed to students and other listeners and could be referred to as "carriers of knowledge". These carriers of knowledge include video tapes, computer, diskettes, CD-Roms, disks. Meanwhile, Empirica (2006) categorizes ICT as video conferencing, laptops or games or handheld technologies such as personal digital assistance (PDA) while in the findings of Slaout and Horton (2007), the most commonly used ICT devices by teachers are word-processing, power point and World Wide Web (www). In Malaysia, a wide range of ICTs such as laptops, LCD projectors, trolley with speakers, software like PowerPoint, flash and interactive courseware have been used to support teaching and learning throughout schools (Bee, Lau and Chia, 2008).

Suffice it to state here that ICTs should not be seen from the ordinary use of modern electronic equipment like radio, television but from the new communication and telecommunication technologies that use interconnection of computer resources and supporting equipment to process, manage and transfer information. Hence, modern ICTs are nearly synonymous with the use of computer to store, process, retrieve and transfer information.

The use of ICT in education and training has been a key priority in the educational sector. Eurydice (2004) observes that some schools in developing countries have embedded ICT into their curriculum and they have demonstrated high level of effective and appropriate use of it to support teaching and learning. This use of ICT cuts across a wide range of subject areas. Ramboll (2005) examines the contributions of ICT in education and states the following benefits:

1. Supports reading, writing and language skills of the students

2. Strengthens students' general ICT and media skills

3. Supports inter-disciplinary work

4. Makes schooling more inclusive

5. Encourages new learning methods,

At this juncture, it is doubtless to say that ICT is applicable to education because the Commonwealth of Learning (2002) identifies the uses of ICT in education to include e-learning which takes place via various means which include blended learning and teleconferencing; e-library and e-board.

On the part of the teacher, the use of ICT in teaching the English Language has been discovered through different studies to have positive influence on such a teacher because it increases his/her enthusiasm for the use of ICT (Jennings and Onwuegbuzie, 2001; European Schoolnet, 2004); it increases teachers' efficiency (Underwood, 2006; Jegede, 2007); it increases co-operation and planning (Armstrong, 2004). On the part of the learner, Look (2005) indicates that students in technology-rich environment experience positive effects on performance in all subject areas, while Barak (2007) observes that the use of interactive multimedia software motivates students and leads to improved performance. In all, the use of ICT in teaching and learning of English would enhance students' performance but it is desirable to determine the attitude of teachers and students to its use in English language instruction in senior secondary schools in Awka.

\section{Statement of the Problem:-}

The emergence of ICT has had considerable effect on different sectors of human life especially among advanced nations but these invaluable advantages have not been fully utilized by developing nations. More importantly, the use of ICT has not been fully exploited in the teaching and learning of English Language. This may not be 
unconnected with the subjects' attitude to this modern innovation. Against this background, this study aimed at investigating the attitude of teachers and students to the use of ICT in teaching and learning of English Language in senior secondary schools in Awka metropolis.

\section{Research Questions:-}

The following research questions drive this study:

1. What is the attitude of English teachers towards the application of ICT in English Language teaching?

2. What is the attitude of students towards ICT-based instruction in English Language?

3. What ICT facilities are used by learners to facilitate English Language learning?

4. On which aspects of English Language can English teachers apply their Knowledge of ICT?

\section{Significance of the Study:-}

This study is significant because it will help English Language teachers recognize the inestimable roles that ICT play in lesson delivery and the overall performance of their students in any examination. Also, it will enable students to recognize ICT facilities that they can use to facilitate effective learning of the English language. On the part of the government, this study will assist government to plan, implement, monitor and evaluate its policy towards language education and it will help schools to see the need to integrate ICT into teaching any school subject, especially, the English Language.

\section{Theoretical Framework:-}

The theory underpinning this study is the theory of attitude formation and change propounded by Gordon Allport in 1935. He submits that attitude can be formed from an individual's past or present and that it can be a positive or negative evaluation of people, objects, events, activities and idea about anything in the environment. Building on Allport, Green (1953) submits that attitude is an abstraction from a large number of related activities or responses while Katz (1960) says it is the pre-disposition of an individual to evaluate some symbol or object or aspect of his world in a favourable or an unfavourable manner.

Attitude is an important construct in the teaching and learning situation as students' attitude to a .subject has to do with emotional reactions, behavioural tendencies and beliefs about that particular subject which could be positive or negative. A lot of studies have been carried out on attitude and across disciplines. In the humanities, for instance, Muhammad (2001) reports that students' attitude to Literature-in-English in Malaysia is negative but Siregar (2010) discovers a positive attitude to learning Literature-in English in Southeast Asia.

In another study in Turkey, Yilmaz (2012) reports that teachers' instructional method has a positive influence on students' attitude to Literature-in-English in Turkey and Osisanlu (2012) in Nigeria, investigates the extent to which method of teaching influences students' attitude to poetry. While studies cited are on Literature-inEnglish which is delivered in English language, a study of how the use of Information and Communication Technology (ICT) determines the attitude that students have toward English is desirable, especially in this age of ICT.

\section{Research Design:-}

This study adopted survey research design because no attempt was made to manipulate the variable in the study.

\section{Population and Selection of Subjects:-}

The population for this study comprised teachers and students ot English Language at the Senior Secondary School level in Awka. Simple random technique was used to select twenty-two out of the seventy-four secondary schools in the two local government areas in Awka metropolis. An intact class of senior secondary II class was used in each school for this study, thus a total of 296 students were used. All teachers of English at the senior secondary level were used in these schools, giving a total of 45 . Altogether, a total of 311 subjects participated in this study.

\section{Research Instruments:-}

Two distinct instruments were used to collect data for this study. The teacher questionnaire titled "Teacher Questionnaire on Attitude to the Use of Information and Communication Technology (ICT)" was a closeended one patterned after the modified Likert four-point scale of Strongly Agree (SA), Agree (A), Disagree (D) 
and Strongly Disagree (SD). The instrument had three sections. Section A was on demographic data, section B was on perceived areas in English where ICT could be applied, and section C was on teacher attitude toward ICT. In the same vein, the students' questionnaire was titled "Students' Questionnaire on Attitude to the Use of Information and Communication Technology in the Learning of English Language". It was patterned after the teachers' instrument.

\section{Validation of Instruments:-}

The face and content validity of the instruments were determined by showing them to secondary school teachers of English and experts in English Language and Computer and necessary modifications were made. The reliability of the two instruments was determined through test-retest using Cronbach Alpha. The index of the teacher instrument was . 75 while that of the student was .69 thus confirming that they were reliable.

\section{Procedure for Data Collection:-}

The instruments were personally taken to the selected schools and the permission of the principals' and teachers' consent was sought. The teachers assisted in administering the instrument on the students. On some occasions, the researcher had to visit some respondents twice before the instrument could be collected from the teachers. In all, the administration of data for this study lasted five weeks.

\section{Method of Data Analysis and Results:-}

The data collected were analysed using descriptive statistics of frequency count, percentage score and chi-square.

The results of the research questions are presented below:

Research Question 1:- What is the attitude of English teachers towards the application of ICT in English Language teaching?

Table 1:- Teachers' Attitude Towards ICT in English Language Teaching

\begin{tabular}{|c|c|c|c|c|c|c|}
\hline S/No & ITEMS & SA & $\mathbf{A}$ & D & SD & TOTAL \\
\hline \multirow[t]{2}{*}{1.} & ICT will Influence & 19 & 27 & 0 & 0 & 46 \\
\hline & Teaching positively & $(41.3 \%)$ & $(58.7 \%)$ & $(0.0 \%)$ & $(0.0 \%)$ & $(100 \%)$ \\
\hline \multirow[t]{3}{*}{2.} & Knowledge of ICT makes & 29 & 17 & 0 & 0 & 46 \\
\hline & English Teachers & $(63 \%)$ & $(37 \%)$ & $(0.0 \%)$ & $(0.0 \%)$ & $(100 \%)$ \\
\hline & Productive & & & & & \\
\hline \multirow[t]{4}{*}{3.} & ICT in & 2 & 7 & 29 & 8 & 16 \\
\hline & secondary & $(4.3 \%)$ & $(15.2 \%)$ & $(63 \%)$ & $(17.4 \%)$ & $(100 * *)$ \\
\hline & School hinders & & & & & \\
\hline & fast learning & & & & & \\
\hline \multirow[t]{4}{*}{4.} & ICT-based & 2 & 10 & 27 & 7 & 46 \\
\hline & teaching is not & $(1.3 \%)$ & $21.7 \%)$ & $(58,7 \%)$ & $(15.0 \%)$ & $(100 \%)$ \\
\hline & applicable in & & & & & \\
\hline & Secondary schools & & & & & \\
\hline \multirow[t]{3}{*}{5.} & Difficulties in & 9 & 26 & 11 & 0 & 46 \\
\hline & ICT usage don't & $(19.6 \%)$ & $(56.5 \%)$ & $(23.9 \%)$ & $(0.0 \%)$ & $(100 \%)$ \\
\hline & hinder me & & & & & \\
\hline \multirow[t]{5}{*}{6.} & ICT facilities may & 2 & 17 & 24 & 3 & 46 \\
\hline & confuse & $(4.396)$ & $(37 \%)$ & $(52.2 \%)$, & $(6.5 \%)$ & $(100 \%)$ \\
\hline & students in & & & & & \\
\hline & English & & & & & \\
\hline & teaching & & & & & \\
\hline \multirow[t]{4}{*}{7.} & Interaction & 22 & 3 & 19 & 2 & 46 \\
\hline & with & $(47.8 \%)$ & $(6.5 \%)$ & $(41.3 \%)$ & $(4.3 \%)$ & $(100 \%)$ \\
\hline & computers & & & & & \\
\hline & excites me & & & & & \\
\hline \multirow[t]{3}{*}{8.} & Erratic power & 4 & 20 & 22 & 0 & 46 \\
\hline & supply hinders & $(8.7 \%)$ & $(43.5 \%)$ & $(47.8 \%)$ & $(0.0 \%)$ & $(100 \%)$ \\
\hline & ICT & & & & & \\
\hline
\end{tabular}




\begin{tabular}{|l|l|l|l|l|l|l|}
\hline & application & & & & & \\
\hline 9. & Cos of & 2 & 23 & 19 & 2 & 46 \\
\hline & maintaining & $(4.3 \%)$ & $(50 \%)$ & $(41.3 \%)$ & $(4.3 \%)$ & $(100 \%)$ \\
\hline & ICT is & & & & & \\
\hline & exorbitant & & & & & \\
\hline 10. & It is not advisable for & 0 & 4 & 24 & 18 & 46 \\
\hline & English Language & $(0.0 \%)$ & $(8.7 \%)$ & $(52.2 \%)$ & $(39.1 \%)$ & $(100 \%)$ \\
\hline & teachers to give assignment & & & & & \\
\hline & requiring ICT & & & & & \\
\hline & ICT usage & & & & & \\
\hline
\end{tabular}

From Table 1 above, all the English teachers believed that the use of ICT would influence the teaching of English Language positively (100\%). This, they further reiterated by agreeing that the knowledge of ICT made the teaching of English productive. However, a few of the teachers, 21 (U.6\%), still did not derive any excitement when interacting with the computer. Also, some of the respondents, 21 (45.6\%), believed that the cost of maintaining ICT was exorbitant.

Research Question 2: What is the attitude of Students toward ICT-based instruction in English Language?

Table 2:- Students' Attitude towards ICT-based instruction in English Language

\begin{tabular}{|c|c|c|c|c|c|c|}
\hline $\mathrm{S} / \mathrm{NO}$ & ITEMS & SA & $\mathrm{A}$ & $\mathrm{D}$ & SD & TOTAL \\
\hline \multirow[t]{5}{*}{1.} & Browsing is & 117 & 120 & 21 & 38 & 296 \\
\hline & meant for & $(39.5 \%)$ & $(10.5 \%)$ & $(7.1 \%)$ & $(12 . \mathrm{S} \%)$ & $(100 \%)$ \\
\hline & students in & & & & & \\
\hline & science and & & & & & \\
\hline & Technology & & & & & \\
\hline \multirow[t]{3}{*}{2.} & CD, DVD etc. make & 63 & 72 & 68 & 93 & 296 \\
\hline & learning & $(21.3 \%)$ & $(21.3 \%)$ & $(23.0 \%)$ & $(31.1 \%)$ & (10096) \\
\hline & difficult & & & & & \\
\hline \multirow[t]{3}{*}{3.} & I don't care if & 111 & 116 & 6 & 11 & 296 \\
\hline & virus infects a & $(38.2 \%)$ & $(39.2 \%)$ & $(2.0 \%)$ & $(3.7 \%)$ & $(100 \%)$ \\
\hline & Computer & & & & & \\
\hline \multirow[t]{8}{*}{4.} & Learning & 109 & 19 & 18 & 90 & 296 \\
\hline & through & $(36.8 \%)$ & $(16.6 \%)$ & $(16.2 \%)$ & $(30.4 \%)$ & $(100 \%)$, \\
\hline & books, & & & & & \\
\hline & newspapers, & & & & & \\
\hline & magazines is & & & & & \\
\hline & preferable to & & & & & \\
\hline & learning & & & & & \\
\hline & through ICT & & & & & \\
\hline \multirow[t]{4}{*}{5 , } & Attending & 97 & 170 & $\mathrm{U}$ & 11 & 296 \\
\hline & training in & $(32.2 \%)$ & $(37.1 \%)$ & $(13.8 \%)$ & $(3.7 \%)$ & $(100 \%)$ \\
\hline & ICT is time & & & & & \\
\hline & Wasting & & & & & \\
\hline \multirow[t]{6}{*}{6.} & Computers & 113 & 116 & 30 & 37 & 296 \\
\hline & should replace & $(38.2 \%)$ & $(39.2 \%)$ & $(10.1 \%)$ & $(12.5 \%)$ & $(100 \%)$ \\
\hline & textbooks in & & & & & \\
\hline & teaching and & & & & & \\
\hline & learning in & & & & & \\
\hline & schools today & & & & & \\
\hline \multirow[t]{2}{*}{7.} & Computer, & 100 & 73 & 101 & 75 & 296 \\
\hline & VCD, DVD & $(33.8 \%)$ & $(21.7 \%)$ & $(35.1 \%)$ & $(25.3 \%)$ & $(100 \%)$ \\
\hline
\end{tabular}




\begin{tabular}{|l|l|l|l|l|l|l|}
\hline & etc. are less useful & & & & & \\
\hline & for learning English & & & & & \\
\hline & Language & & & & & \\
\hline 8. & I like e- learning & 113 & 43 & 39 & 101 & 296 \\
\hline & & $(38.2 \%)$ & $(11.5 \%)$ & $(13.2 \%)$ & $(31.1 \%)$ & $(100 \%)$ \\
\hline 9. & I can't use & 8 & 94 & 39 & 65 & 296 \\
\hline & ICT because I & $(33 \%)$ & $(31.8 \%)$ & $(13.2 \%)$ & $(22.0 \%)$ & $(100 \%)$ \\
\hline & don't understand & & & & & \\
\hline & Its use. & & & & & \\
\hline 10. & Teachers who use ICT & 98 & 100 & 40 & 58 & 296 \\
\hline & For teaching create & $(33.1 \%)$ & $(33.8 \%)$ & $(13.5 \%)$ & $(19.6 \%)$ & $(100 \%)$ \\
\hline & problems for me & & & & & \\
\hline
\end{tabular}

Table 2 above reveals that $237(80 \%)$ of the students were of the opinion that browsing was meant for students in the science and technology-based disciplines hence, 158 (53.4\%) of them still believed that it was better to learn through printed materials than ICT; 267 (70.2\%) equally believed that attending training in ICT was a waste of time. However, there is no correlation between this opinion of the students and their response that computers should replace textbooks in teaching and learning in schools today. This is buttressed by their response where $156(52.7 \%)$ said they liked e-learning and $110(47.3 \%)$ said they did not like e-learning.

Research Question 3:- What ICT Facilities are used by Learners to Facilitate English Language learning?

Table 3:- ICT Facilities commonly used by English Learners

\begin{tabular}{|c|c|c|c|c|c|c|}
\hline $\mathrm{S} / \mathrm{N}$ & ITEMS & \multicolumn{2}{|c|}{ YES } & \multicolumn{2}{|c|}{$\mathrm{NO}$} & \multirow[t]{2}{*}{ TOTAL } \\
\hline & & $\mathrm{N}$ & $\%$ & $\mathrm{~N}$ & $\%$ & \\
\hline 1. & school possess a website? & 231 & 78.0 & 65 & 32.0 & $296(100 \%)$ \\
\hline \multirow[t]{3}{*}{2.} & Is there a language & 10 & 3.4 & 286 & 96.4 & 296 \\
\hline & laboratory in your & & & & & $(100 \%)$ \\
\hline & school? & & & & & \\
\hline \multirow[t]{2}{*}{3.} & Do you have access to & $\ldots$ & 75.0 & 74 & 25.0 & 296 \\
\hline & desktop/laptop? & & & & & $(100 \%)$ \\
\hline \multirow[t]{3}{*}{4.} & Have you heard about & 68 & 23.0 & 228 & 77.0 & 296 \\
\hline & interactive board & & & & & $(100 \%)$ \\
\hline & before? & & & & & \\
\hline \multirow[t]{2}{*}{5.} & Does your school have & 64 & 21.6 & 232 & 78.4 & 296 \\
\hline & e-library? & & & & & $(100 \%)$ \\
\hline \multirow[t]{3}{*}{6.} & Do you have & 251 & 84.8 & 15 & 15.2 & $2 \%$ \\
\hline & generating set in your & & & & & $(100 \%)$ \\
\hline & school? & & & & & \\
\hline \multirow[t]{2}{*}{7.} & Do you have software & 135 & 45.6 & 161 & 54.4 & 296 \\
\hline & on English language? & & & & & $(100 \%)$ \\
\hline \multirow[t]{3}{*}{8.} & Are your teachers using & 180 & 60.8 & 116 & 39.2 & 296 \\
\hline & English language & & & & & $(100 \%)$ \\
\hline & software? & & & & & \\
\hline \multirow[t]{2}{*}{9.} & Do you have internet & 159 & 53.7 & 137 & 46.3 & 296 \\
\hline & facilities at home': & & & & & $(100 \%)$ \\
\hline \multirow[t]{2}{*}{10.} & Is your phone & 169 & 57.1 & 127 & 42.9 & 296 \\
\hline & multimedia? & & & & & $(100 \%)$ \\
\hline
\end{tabular}

With reference to Table 3, a total of 231 (78\%) of the students said their schools had websites while 222 $(75 \%)$ of them had access to the computer, either at home or in school. However, most of the selected schools did not have e-libraries, which would have afforded the students the opportunity to access the internet. Meanwhile, a sizeable number of them had internet facilities at home which meant they could make use of compact disk, hard drive, video compact disk, radio, computer and telephone to access information. The 
table further reveals that most students 286 (96.4\%) did not have language laboratory in their schools although a large number- $180(60.8 \%)$ responded that their teachers used software to teach them language.

Research Question 4:- On which aspects of English language can English teachers apply their Knowledge of ICT?

Table 4:- Aspects of English Language to which ICT Knowledge is applicable

\begin{tabular}{|c|c|c|c|c|c|c|}
\hline S/No & ITEMS & SA & $\overline{\mathrm{A}}$ & $\bar{D}$ & SD & TOTAL \\
\hline \multirow[t]{5}{*}{1} & ICT & 15 & 27 & 3 & 1 & 46 \\
\hline & enhance & $(32.6 \%)$ & $(58.7 \%)$ & $(6 . \%)$ & $(2.2 \%)$ & $(100 \%)$ \\
\hline & students' & & & & & \\
\hline & performance & & & & & \\
\hline & in oral English & & & & & \\
\hline \multirow[t]{6}{*}{2.} & ICT cannot & 5 & $\mathrm{~T}$ & 22 & 15 & 46 \\
\hline & enhance & (10.996) & $(8.7 \%)$ & $(47.8 \%)$ & $(32.6 \%)$ & $(100 \%)$ \\
\hline & vocabulary & & & & & \\
\hline & development & & & & & \\
\hline & students & & & & & \\
\hline & and teachers & & & & & \\
\hline \multirow[t]{6}{*}{3.} & Poor writing & 8 & 30 & 4 & 4 & 46 \\
\hline & can be & $(17.4 \%)$ & $(65.2 \%)$ & $(8.7 \%)$ & $(8.7 \%)$ & $(100 \%)$ \\
\hline & rectified using & & & & & \\
\hline & specified word & & & & & \\
\hline & processing & & & & & \\
\hline & software & & & & & \\
\hline \multirow[t]{3}{*}{4.} & Software can & 14 & 17 & 11 & 4 & 46 \\
\hline & improve poor & $(30.4 \%)$ & $(37.0 \%)$ & $(23.9 \%)$ & $(8.7 \%)$ & $(100 \%)$ \\
\hline & listening & & & & & \\
\hline \multirow[t]{4}{*}{5.} & Poor grammar & 11 & 30 & 2 & 0 & 46 \\
\hline & can be & $(30.4 \%)$ & $(65.2 \%)$ & $\mathrm{U} .3 \%)$ & $(0.0 \%)$ & $(100 \%)$ \\
\hline & corrected via & & & & & \\
\hline & ICT & & & & & \\
\hline \multirow[t]{6}{*}{6.} & Grammar and & 21 & 21 & 4 & 0 & 46 \\
\hline & spelling & $(-15.7 \%)$ & $(-15.7 \%)$ & $(8.7 \%)$ & $(0.0 \%)$ & $(100 \%)$ \\
\hline & checks help & & & & & \\
\hline & students write & & & & & \\
\hline & error-free & & & & & \\
\hline & English & & & & & \\
\hline \multirow[t]{6}{*}{7.} & Access to the & 5 & $1 \mathrm{C}$ & 21 & 1 & 46 \\
\hline & internet & $(10.9 \%)$ & $\langle 34 \mathrm{r} \ll)$ & $(45.7 \%)$ & $(8-7 \%)$ & $(100 \%)$ \\
\hline & impedes & & & & & \\
\hline & students' & & & & & \\
\hline & reading & & & & & \\
\hline & proficiency & & & & & \\
\hline \multirow[t]{4}{*}{8.} & Lexis and & 13 & 29 & 3 & 1 & 46 \\
\hline & structure can & $(28.3 \%)$ & (6396) & $(6-5 \%)$ & $(2.2 \%)$ & $(100 \%)$ \\
\hline & be taught & & & & & \\
\hline & through ICT & & & & & \\
\hline \multirow[t]{6}{*}{9.} & Access to & 10 & 13 & 19 & 4 & 46 \\
\hline & Dictionary, & $(21.7 \%)$ & $(28.3 \%)$ & $* \%)$ & $(8.7 \%)$ & $(100 \%)$ \\
\hline & software & & & & & \\
\hline & inhibits & & & & & \\
\hline & vocabulary & & & & & \\
\hline & acquisition & & & & & \\
\hline
\end{tabular}




\begin{tabular}{|l|l|l|l|l|l|l|}
\hline 10. & Multimedia & 10 & 19 & 13 & 1 & $\cdot 16$ \\
\hline & activities such & $(21.7 \%)$ & $<11.7 * 1$ & $(28.0 \%)$ & $(8.6 \%)$ & $(100 \%)$ \\
\hline & as games. & & & & & \\
\hline & video camera, & & & & & \\
\hline & voice recorder & & & & & \\
\hline & etc. can & & & & & \\
\hline & improve & & & & & \\
\hline & proficiency in & & & & & \\
\hline & English & & & & & \\
\hline
\end{tabular}

Table 4 reveals that all aspects of English Language can be taught using ICT. For example, 42 (91.3\%) of the teachers responded that ICT could be used to teach and enhance students performance in oral English; 37 $(80.1 \%)$ responded that it could enhance students' and teachers' vocabulary development; $41\left(95.6^{\prime} \%\right)$ believed ICT could help correct poor grammar; $31(67.4 \%)$ responded that ICT could improve poor listening, while 42 (91.3\%) of them responded that lexis and structure would be improved through ICT. In essence, the application of ICT can enhance all aspects of English Language teaching and learning in secondary schools.

\section{Discussion of Findings:-}

From this study, it has been established that the use of ICT by teachers of English will influence their teaching of the subject as the teachers sampled were favourably disposed to its use. This is in line with the submission of Machin (2006) and Oyinloye (2007). It is a fact that the knowledge of ICT enhances performance. However, a few of the teachers did not derive any excitement in interacting with ICT facilities, particularly the computer.

Also, from this study, it is revealed that most students believed that ICT is only useful in the sciences and technology. This attitude might be responsible for the poor performance that is still being recorded in English. It is believed that if teachers arouse students' attention through the use of ICT, as Bradley and Hitch (2001) submit, it would improve their performance in the subject

Furthermore, it has been discovered through this study that the commonest ICT facilities that are available to the respondents are mobile phones and the computer. These facilities could be maximized in teaching every aspect of English Language, even in the rural areas. This is because many types of softwares that treat various aspects of English language can be downloaded into these gadgets and used in the classroom. However, a better and an easier way of enhancing English language lessons would have been through the internet and this would require regular electricity supply which is still a mirage in Nigeria.

Finally, this study indicates that all aspects of English language can be taught with ICT. According to Eurydice (2001) and Jegede (2007), the use of ICT in teaching English will enhance performance. Therefore, Computer Aided Instruction (CAI) should be provided to enhance students' learning. (Yusuf and Afolabi, 2010).

\section{Conclusion and Recommendations:-}

In the light of the findings of this study, it can be concluded that teachers of English at the Senior Secondary School level and their students are knowledgeable in ICT. Also, it has been established that teachers have positive attitude towards the use of ICT in teaching English but students' attitude need to change as they have the impression that ICT is only science-based. This is not to say that students have no knowledge of ICT as majority of them can manipulate computers and mobile phones.

While many teachers are eager to use their knowledge of ICT to teach English, erratic supply of electricity is a major challenge and most schools cannot provide money to power the generating sets owned by them. It is highly pathetic also that many schools have science laboratories but none of the schools sampled had a language laboratory. In addition, internet facilities that would enhance e-learning are not in most of the schools.

Based on these findings, the following recommendations are offered:

1. Government at all levels should invest in the procurement of ICT facilities in our schools.

2. Computer literacy should he given more attention by all stakeholders. 
3. Teachers in training should undergo training in ICT in order to teach more effectively.

4. The current English Language curriculum should be reviewed to accommodate the use of ICT in teaching and learning of English.

5. Students and teachers should be exposed to various software for English Language teaching and learning.

6. Students' interest should be directed towards taking advantage of the educational dimensions of mobile phones.

7. There should be stable electricity supply to enhance teaching and learning.

\section{References:-}

Allport, G. (1935) Attitudes. In C. Murchimson (Ed.) A Handbook of Social Psychology. Worcester, M. A.: Clark University Press. 789-844.

Armstrong, D, (2004). Moving towards E-Learning in Schools and Federal Colleges. Price-water House Coopers. Retrieved from http://www.dfcs.gov.uk/rcsearch.17March2009

Bamidele, S.O. (2001). Computer Science Education for Tertiary Institution. Journal of Computer Education 4, 17 - 20

Barak, M. (2007). Instructional Principles for fostering learning with ICT, Education Information Technology, $11.121-135$

Bee, T., Lau, C. and Chia, H.S. (2008). Exploring the Extent of ICT Adoption among Secondary School Teachers, International Journal of Computing and ICT Research 9 - 36.

Bradley, G. and Hitch, GJ. (2001). Recent Advances in Learning and Motivation. New York: Academy Press. $817-890$.

British Educational Communication and Technology Agency (2006). What research says about ICT and whole school improvement. Retrieved from http://becta.org.uk 15 September, 2009.

Commonwealth of Learning (2002). An Introduction to Open and Distance Learning. Retrieved from http: wwvv.co.org. Intro/ODL.htm Empirica (2006). Benchmarking Access and use of ICT in European Schools. Empirica 2006.

European Schoolnet (2004) ERNIST ICT School Portraits. Retrieved from $\mathrm{http} /$ /insighteun.org/ww/en/pubinsightschoolinnovation/best practice/ernistschoolportraits CF3. Eun'dice (2001). Key Data on ICT in Schools. Brussels. Retrieved from hup://www.eun ${ }^{\mathrm{r}}$ (Hcc.org/rcsourccs/cunxlu-e/pdi' on 18 October, 2009.

Ezeokoli, E.O. (2000). The Role of language Teacher in Literacy Education in Nigeria. Paper presented at the 7th Conference on Educational Development in Lagos State July 18 - 21 Green, B. F. (1953) Attitude Measurement in Lindzey, Gardiner (ed.) Handbook of Social Psychology. Vol. 1. Reading: Wesley.

Jegede, P.O. (2007). Relationship between ICT Competence and Attitude among Nigerian Tertiary Institution Lecturers. Educational Research and Review2) 172- 175.

Jennings, S.E. and Onwuegbuzie, AJ. (2001). Computer Attitude as a Function of Age, Gender, Attitude and Developmental Status. Journal of Educational Computing Research 25(4).

Katz, D. (1960) The Functional Approach to the Study of Attitudes. Public Opinion Quarterly24, 163204.

Kolawole. C.O.O. (2006). Attitude to the Use of ICT in the Teaching of English language in selected Junior Secondary Schools in Ibadan. Journal of Computer literacy 7 $) 1-15$.

Look, D. (2005). Impact of Technology on Education. Retrieved from http/p[easantonkl2.ca.us/superintendent on 18 October.

Machin, S. (2006). New Technologies in Schools. Germany. Retrieved from http://ftpiza.Org/dp2234.pdfon 28 Aug 2009.

Makindc, S.O. (2003). Subject Preference among Secondary School Students in Lagos Slate: Implications for the teaching of Nigeria Languages in the New Millennium in New Dimension in Educational Development. Faculty of Education. Lagos State-University. 51 - 63.

Mayer, R.E. (2001), Multimedia Learning. Cambridge: Cambridge University Press.

Muhammad, S. A. R. (2001) A Study of Students' and English Teachers' Attitudes towards the Learning of Literature in selected schools in the District of Kuala. Terengannu: Malaysia.

Onwuamanam, D.O. and Owuamanam, T.O. (2004). Fundamental of Educational Psychology. Lagos: Bolaboy Publications. 
Osisanlu, O. O. (2012) Effects of Three Methods of Teaching Poetic Literature on Students' Achievement and Attitude to Reading Comprehension on English Language. A Post-field Seminar Paper. Department of Teacher Education, university of Ibadan, Ibadan.

Oyinloye, G.O. (2007). Language and Literature Teaching Methods. Lagos: Bifocal Publishers.

Ramboll Management (2005). Evaluation of ITME: Overall Results. Retrieved from http://cnis.enu.dk./spredning/itmf/ on 28 August, 2009.

Renee, W. (1996). The Roles of Computer in Teaching EFL to Dyslexic Students.

Slaout, D. and Borton, A. (2007). Opportunities for Practice and Development of New Qualified Teachers and the Use of Information and Communication Technology in Teaching Foreign Languages. Journal of in-Service Education 33.

Siregar, F. L. (2010) The Language Attitudes of Students of English Literature and D3 English at Maranatha Christian University Towards American English, British English and Englishes in Southeast Asia and Their Various Contexts of Use in Indonesia, Philippine. ESL Journal, Vol. 4, February.

Underwood, J. (2006). ICT Test Based Evaluation - Evaluation of the ICT Test, UK, Nottingham Trent University. Retrieved from http://www.cvaluation.ictcst-bed.org.uk on 28 August, 2009.

UNESCO (2005). Information and Communication Technologies in Schools. A Handbook for Teachers on How ICT Can Create New, Open Learning Environment. Retrieved from http:/Unesco on 27 August, 2009.

Yilmaz, C. (2012) Introducing literature to an EFL Classroom: Teacher's Instructional Methods and Students' Attitudes Towards the Study of Literature. Canakkle Onsekiz University, Faculty of Education, Department of English, Turkey.

Yusuf, M.O. and Afolabi, A.O. (2010). Effects of Computer Assisted Instruction on Secondary School Students' Performance in Biology. Journal of Educational Technology 9, 62 - 69. 